\title{
KEPEMIMPINAN (LEADERSHIP)
}

\author{
Siti Humaeroh \\ Fakultas ushuluddin \\ UIN sultan maulana hasanuddin banten \\ e-mail: sitihumaeroh1410@gmail.com
}

\begin{abstract}
ABSTRAK
Kepemimpinan (leadership) berkenaan dengan seseorang memengaruhi perilaku orang lain untuk suatu tujuan. Dengan kekuasaan, pemimpin dapat memengaruhi perilaku para bawahannya. Kekuasaan dapat dibagi menjadi lima, yaitu: (1) kekuasaan keahlian (expert power); (2) kekuasaan legitimasi (legitimate power); (3) kekuasaan referensi (referent power); (4) kekuasaan penghargaan (reward power); dan (5) kekuasaan paksaan (coercive power). Disamping berhubungan dengan kekuasaan, kepemimpinan juga erat kaitannya dengan karakter. Berbagai upaya riset dilakukan untuk mengidentifikasi karakter-karakter yang konsisten dengan kepemimpinan. Upaya riset yang dilakukan untuk memisahkan karakter kepemimpinan banyak menemui jalan buntu. Dinyatakan juga bahwa pencarian untuk mengidentifikasi seperangkat karakter yang membedakan pemimpin dan pengikut dan antara pemimpin yang efektif dan tidak efektif, banyak yang gagal. Hasil yang paling dapat diterima adalah riset yang bertujuan hanya untuk melakukan identifikasi terhadap karakter-karakter yang dapat dikaitkan secara konsisten dengan kepemimpinan.
\end{abstract}

Kata kunci: kepemimpinan

\begin{abstract}
Leadership relates to a person's behavior with respect to another person for a purpose. With power, leaders can influence the behavior of their subordinates. Power can be divided into five, namely: (1) expert power, (2) legitimate power, (3) referent power, (4) reward power, and (5) coercive power. Besides dealing with power, leadership is also closely associated with the character. Various research efforts carried out to identify the characters that are consistent with
\end{abstract}


the leadership. Research efforts are made to separate the leadership's characters, but it was found deadlock. Also stated that the quest to identify a set of characters that distinguishes between a leader and followers and effective leaders and effective, many have failed. Most acceptable result is research that aims only to identify the characters that can be linked consistently with leadership.

Keywords: leadership

\section{PENDAHULUAN}

Pemimpin dan kepemimpinan selalu menarik dibicarakan oleh berbagai lapisan masyarakat. Seperti para guru/dosen, pelajar/mahasiswa, pengusaha, birokrat, orang tua, pemuda, seniman, olahragawan, cendekiawan, politikus dan sebagainya. Pada intinya semua yang terikat dengan orang lain atau dengan perkumpulan, himpunan, asosiasi, lembaga dan organisasi. Semuanya tidak dapat terlepas dari pembahasan tentang pemimpin dan kepemimpinan. Adapun di dalam Al-Qur'an, terdapat banyak ayat yang menerangkan tentang jiwa-jiwa kepemimpinan. Salah satunya, Allah berkalam dalam QS. AliImran: 159.

Pada ayat tersebut berkaitan dengan peristiwa pasca perang Uhud. Di mana, dalam kondisi evaluasi kerja, tidak jarang seorang pemimpin terjebak dalam emosi. Bahkan, dapat berbuat semena-mena terhadap anggotanya yang dianggap sebagai penyebab kegagalan tersebut. Apa yang dilakukan Rasulullah Saw. - dengan bimbingan dari Allah- terhadap sahabatnya telah memberikan contoh yang sungguh mulia bagi seorang pemimpin. Sikap beliau terhadap mereka - walaupun sebagian dari mereka telah lari dari medan perang - tetap santun, tidak kasar, tidak keras hati, mudah memaafkan dan memintakan ampun atau dosa mereka kepada Allah SWT. Bahkan, untuk mengembalikan kepercayaan antara pemimpin dan umatnya, beliau tidak segansegan mengajak mereka kembali untuk memperbaiki kondisi dengan mengajak musyawarah. Sikap mulia semacam itu ditegaskan sebagai rahmat (keberkahan) Allah yang diberikan kepada Rasulullah SAW, untuk bisa menjadi contoh bagi seluruh umatnya (Lihat QS. At-Taubah: 128). 
Karena itu, banyak orang beranggapan bahwa maju dan berkembangnya suatu organisasi terletak pada pemimpinnya. Begitu juga sebaliknya, organisasi yang tidak dapat berkembang bahkan mengalami penurunan, bisa dimungkinkan penyebabnya adalah lemahnya pemimpin. Hal demikian berlaku bagi semua organisasi yang bergerak, termasuk salah satunya adalah organisasi yang bergerak dalam bidang pendidikan (lembaga pendidikan). Apabila ingin memajukan dan mengembangkan organisasi atau lembaga apapun, maka salah satu kuncinya terletak pada pemimpin atau kepemimpinan yang ada di dalamnya. Meskipun faktor di luar pemimpinnya baik, jika tidak didukung sumber daya manusia (termasuk pemimpinnya) yang profesional, maka tidak akan dapat berhasil dengan baik.

Kehidupan organisasi selalu dihubungkan dengan siapa pemimpinnya dan bagaimana memimpinnya. Sebuah negara itu maju atau tidak selalu dihubungkan dengan presidennya, baik sebagai kepala negara maupun sebagai kepala pemerintahan. Demikian juga sekolah itu maju atau tidak, selalu dikaitkan dengan kepala sekolahnya. Oleh karena itu, semua orang menyadari bahwa seorang pemimpin memiliki posisi yang sangat strategis dan peran yang sangat vital dalam memajukan atau mengembangkan sebuah organisasi. Hal tersebut kiranya telah difahami bahwa faktor pemimpin dan kepemimpinan sangat besar pengaruhnya terhadap kesuksesan organisasi.

\section{PEMBAHASAN}

\section{PENGETIAN PEMIMPIN}

Kepemimpinan adalah adalah proses mempengaruhi aktivitas-aktivitas sebuah kelompok yang diorganisasi ke arah pencapaian tujuan. ${ }^{1}$ Dalam pengertian lain kepemimpinan adalah kemampuan dan keterampilan seseorang yang menduduki jabatan sebagai pimpinan satuan kerja untuk mempengaruhi orang lain, terutama bawahannya, untuk berfikir dan bertindak sedemikian rupa sehingga melalui perilaku yang positif ia memberikan sumbangan nyata dalam pencapaian tujuan organisasi. Sedangkan penertian manajemen adalah suatu proses perencanaan, pengorganisasian, kepemimpinan dan pengendalian upaya dari anggota organsasi serta

\footnotetext{
${ }^{1}$ Stogdill, 1948
} 
penggunaan semua sumber daya yang ada pada organisasi untuk mencapai tujaun organisasi yang telah ditetapkan sebelumnya. ${ }^{2}$

Hampir setiap literatur-literatur tentang kepemimpinan memberikan gambaran yang ideal tentang kepemimpinan. Hal ini dapat dimengerti, karena masnusia membutuhkan kepemimpinan itu. Dan dari waktu ke waktu kepemimpinan menjadi tumpuan harapan dari manusia, sehingga dewasa ini masalah kepemimpinan semakin menarik perhatian banyak kalangan terutama dalam kajian komtemporer, sebab kepemimpinan memiliki dimensi yang luas.

Menurut kamus besar Bahasa Indonesia, kepemimpinan adalah perihal memimpin; cara memimpin. Kepemimpinan bisa dirumuskan sebagai kiat mempengaruhi orang banyak agar mau bekerjasama memperjuangkan tujuan-tujuan yang ingin mereka capai. ${ }^{3}$ Rebecca kemudian menambahkan bahwa seoarng pemimpin adalah penggerak ke arah usaha bersama yang terorganisasi. Ia merupakan agen atau pelaksana dari suatu kekuasaan yang menggunakan dirinya.

Kusnadi mengemukakan bahwa kepemimpinan tidak saja berarti pemimpin dan mempengaruhi orang-orang, tetapi juga pemimpin terhadap perubahan dan sumber aspirasi serta motivasi bawahan. ${ }^{4}$

Winardi mengartikan bahwa kepemimpinan merupakan suatu kemampuan yang melekat pada diri seseorang yang memimpin, yang tergantung dari macam-macam, faktor-faktor intern maupun ekstern, diantaranya meliputi orang-orang; bekerja dari sebuah posisi organisatoris; dan timbul dalam sebuah situasi yang spesifik. Sehingga kepemimpinan timbul, apabila ketiga faktor tersebut saling mempengaruhi satu sama lain yaitu situasi dan posisi ada, orang-orangnya juga $\operatorname{ada.}^{5}$

Islam menetapkan tujuan dan tugas utama pemimpin adalah untuk melaksanakan ketaatan kepada Allah dan Rasul-Nya serta melaksanakan perintah-perintah-Nya. Ibnu Taimyah mengungkapkan bahwa kewajiban seorang pemimpin yang telah ditunjuk dipandang dari segi

\footnotetext{
2 James A.F. stoner

${ }^{3}$ Rebecca “Analisis Perencanaan Implementasi dan Kontrol”(dalam http://vianney-jkt.sch.id/a185m23s/ kepemimpinan-yang-efektif.html)

${ }^{4}$ Kusnadi “Pengantar Manajemen (Konsepsual \& Perilaku)" 2005 hal. 353

${ }^{5}$ Winardi "Kepemimipinan dalam Manajemen" 2000:47
} 
agama dan dari segi ibadah adalah untuk mendekatkan diri kepada Allah. Pendekatan diri kepada Allah adalah dengan menaati peraturan-peraturan-Nya dan Rasul-Nya. Namun hal itu lebih sering disalah gunakan oleh orang-orang yang ingin mencapai kedudukan dan harta.

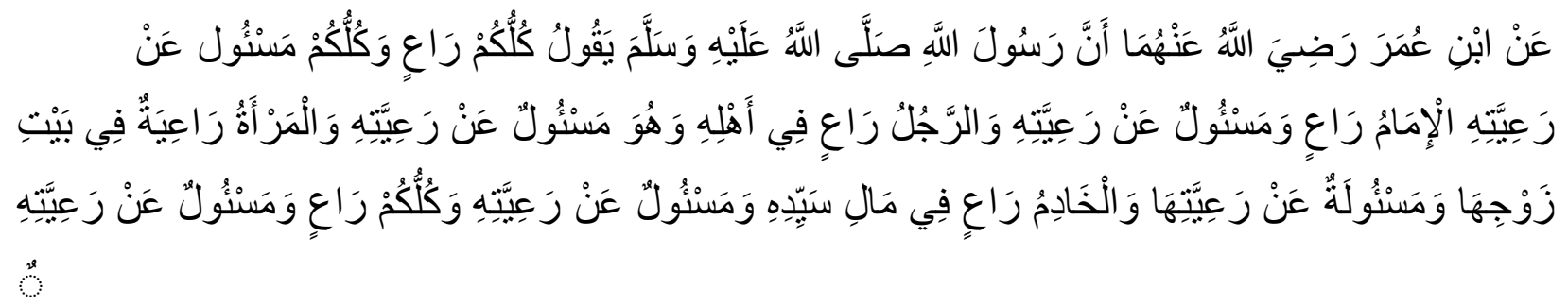

Dari Ibn Umar r.a. Sesungguhnya Rasulullah Saw. Berkata :'Kalian adalah pemimpin, yang akan dimintai pertanggungjawaban. Penguasa adalah pemimpin, dan akan dimintai pertanggungjawaban atas kepemimpinannya. Suami adalah pemimpin keluarganya, dan akan dimintai pertanggungjawaban atas kepemimpinannya. Istri adalah pemimpin dirumah suaminya, dan akan dimintai pertanggungjawaban atas kepemimpinannya. Pelayan adalah pemimpin dalam mengelolaharta tuannya, dan akan dimintai pertanggungjawaban tentang kepemimpinannya. Oleh karena itu kalian sebagai pemimpin akan dimintai pertanggungjawaban atas kepemimpinannya. ${ }^{\mathbf{6}}$

Hal yang paling mendasar yang dapat diambil dari hadis diatas adalah bahwa dalam level apapun, manusia adalah pemimpin termasuk bagi dirinya sendiri. Setiap perbuatan dan tindakan memiliki resiko yang harus dipertanggungjawabkan.

Setiap orang adalah pemimpin meskipun pada saat yang sama setiap orang membutuhkan pemimpin ketika ia harus berhadapan untuk menciptakan solusi hidup di mana kemampuan, keahlian, dan kekuatannya dibatasi oleh sekat yang ia ciptakan sendiri dalam posisinya sebagai bagian dari komunitas.

\footnotetext{
${ }^{6}$ abu 'abd allah Muhammad bin ismail al-bukhari, shahih bukhari, kitab ahkam,bab qoulillahi ta'ala athi'ullah,(berikut lenanon: dar al-kutub al-ilmiyah, 1992), juz VII. H 444
} 


\section{PEMIMPIN YANG ADIL}

Betapa penting pemimpin itu adil, karena pada hakekatnya pemimpin yang adil itu bisa menjamin tegaknya demokrasi. Dalam konteks ini pemimpin seharusnya lebih mengutamakan layanan untuk memenuhi hak yang dilayani (staf atau rakyat).

Keberadaan dan kemajuan suatu organisasi atau institusi sangatlah tergantung pada pemimpinnya. Baik itu berkenaan dengan sifat maupun sikap pemimpin. Adil merupakan salah satu sifat dan sikap pemimpin yang sangat penting, selain jujur, bertanggung jawab, kreatif, visioner, perduli, komunikatif, dan sebagainya. Pemimpin yang adil tidak hanya berurusan secara horizontal, melainkan juga berurusan secara vertikal. Justru pemimpin yang adil ada di mata Allah swt. Dengan begitu betapa berartinya pemimpin yang adil.

Kita bisa amati, mengapa masih banyak praktek korupsi di tanah air. Jika korupsi itu terjadi pada masa Orde Lama atau Orde Baru, maka praktek korupsi yang dilakukan pejabat di semua tempat sangatlah bisa dimaklumi. Walaupun dulu juga sudah ada larangan melakukan pungutan liar (pungli). Namun jika di era Reformasi bahwa praktek korupsi masih ada di manamana, bahkan masih merajalela, sangatlah disayangkan. Karena salah satu misi Reformasi yang penting adalah penghapusan KKN (Korupsi, Kolusi, dan Nepotisme). Berdasarkon kondisi yang ada, dapat diduga secara hipotetik bahwa penyebab utama tindakan korupsi itu adalah kepemimpinan yang tidak adil.

Ronald E Riggio Ph.D. (2018) menjelaskan sejumlah alasan yang menyebabkan pemimpin bertindak tidak adil, di antaranya: Pertama, pemimpin kurang empati. Pemimpin yang berada di posisi tinggi cenderung kurang sensitif terhadap persoalan yang dihadapi staf paling bawah. Kedua, pemimpin cenderung bias. Pemimpin tidak menyadari bahwa mereka berpotensi melakukan bias tertentu yang menjadikan dirinya menyukai orang-orang tertentu daripada yang lainnya. Hal ini sebagai konsekuensi dari adanya praktek "like" and "dislike".

Ketiga, pemimpin tidak dikehendaki untuk bersikap adil. Jika organisasi tidak menekankan perlakuan adil, maka pemimpin merasa bebas untuk melakukan apa saja yang mereka inginkan. Keempat, pemimpin sama sekali kurang panduan. Beberapa pimpinan tidak menyadari bahwa mereka bertindak secara tidak adik dan berbuat apa saja yang disukai. Terakhir, pekerja itu merasa mendapatkan perlakuan tidak adil, padahal pada kenyataannya 
tidak. Terlalu sering pekerja meyakini bahwa mereka diperlakukan secara tidak adil, tetapi pada kenyataannya tidak.

Betapa penting pemimpin itu adil, karena pada hakekatnya pemimpin yang adil itu bisa menjamin tegaknya demokrasi. Dalam konteks ini pemimpin seharusnya lebih mengutamakan layanan untuk memenuhi hak yang dilayani (staf atau rakyat). Memuaskan orang lain lebih diutamakan daripada memuaskan dirinya, keluarganya, koleganya, atau golongannya. Berbuat adil tidak lagi menjadi bisnis duniawiyah melainkan juga bisnis ukhrawiyah. Ingat firman Allah swt, "Dan berlaku adillah. Sesungguhnya Allah menyukai orang-orang yang berlaku adil.” (QS Al Hujurat: 9).

Allah swt tidak hanya perintahkan untuk menjadi pemimpin yang adil, melainkan Allah memberikan jaminan di hari akhir secara eksplisit. Dari Abu Hurairah RA dari Nabi SAW, Beliau SAW bersabda, "Tujuh golongan yang dinaungi Allâh dalam naungan-Nya pada hari dimana tidak ada naungan kecuali naungan-Nya: (1) Imam yang adil, (2) seorang pemuda yang tumbuh dewasa dalam beribadah kepada Allâh, (3) seorang yang hatinya bergantung ke masjid, (4) dua orang yang saling mencintai di jalan Allâh, keduanya berkumpul karena-Nya dan berpisah karena-Nya, (5) seorang laki-laki yang diajak berzina oleh seorang wanita yang mempunyai kedudukan lagi cantik, lalu ia berkata, 'Sesungguhnya aku takut kepada Allâh.' Dan (6) seseorang yang bershadaqah dengan satu shadaqah lalu ia menyembunyikannya sehingga tangan kirinya tidak tahu apa yang diinfaqkan tangan kanannya, serta (7) seseorang yang berdzikir kepada Allâh dalam keadaan sepi lalu ia meneteskan air matanya." (HR Bukhari dan Muslim). Pemimpin yang adil di urutan pertama, menunjukkan betapa Allah swt memberikan perhatian yang khusus.

Bagaimana mengimplementasikan kepemimpinan yang adil, sehingga amanah bisa dipertanggungjawabkan di hadapan Allah swt. Kita sebenarnya sudah memiliki rambu-rambu oleh Allah swt, sehingga kita bisa terhindar dari tindakan KKN. Allah swt berfirman : "Wahai orang-orang yang beriman, jadilah kamu orang yang benar-benar penegak keadilan, menjadi saksi karena Allah biarpun terhadap dirimu sendiri atau ibu bapa dan kaum kerabatmu. Jika ia kaya ataupun miskin, maka Allah lebih tahu kemaslahatannya. Maka janganlah kamu mengikuti hawa nafsu kerana ingin menyimpang dari kebenaran. Dan jika kamu memutar balikkan (katakata) atau enggan menjadi saksi, maka sesungguhnya Allah adalah Maha Mengetahui segala apa 
yang kamu kerjaan.” (QS. An-Nisa': 135). Walaupun sudah ada rambu, ternyata yang memiliki pengetahuan agama yang cukup pun masih terpeleset, sehingga tidak bisa menegakkan keadilan. Maka selalu berlindunglah kepada Allah swt, semoga hidup kita selamat di dunia dan akhirat.

Untuk menjadi pemimpin yang adil dalam suatu organisasi atau institusi, maka ia harus peka terhadap semua orang yang dipimpin, bahkan pihak lain yang terkait. Harus banyak mengamati, mendengar dan bersikap terbuka, jika perlu bersikap proaktif, sehingga dalam memutuskan suatu kebijakan atau keputusan bisa matching dengan apa yang menjadi kebutuhan semua dan dinikmati hasilnya oleh seluruh orang yang dipimpinnya. Tanpa ada salah satu pihak yang diuntungkan ataupun dirugikan. Singkatnya mereka semua harus sama bisa menikmati hasil kerja bersamatanpa ada diskrimasi dan rasa kecewa di salah satu pihak.

Memang tidak semua pemimpin bisa berlaku adil. Untuk berbuat adil tidaklah mudah. Kita perlu mengetahui sanksi dan akibat pemimpin yang tidak adil. Rasulullah saw bersabda "Awal (dari ambisi terhadap kekuasaan) adalah rasa sakit, lalu kedua diikuti dengan penyesalan, setelah itu ketiga diikuti dengan siksa pada hari kiamat, kecuali bagi yang mampu berbuat adil.”(HR At Thantani).

Demikian pula ada peringatan keras bagi pemimpin yang tidak amanah. Nabi SAW bersabda "Sebaik-baik perkara adalah kepemimpinan bagi yang menunaikannya dengan cara yang benar. Sejelek-jelek perkara adalah kepemimpinan bagi yang tidak menunaikannya dengan baik dan kelak ia akan merugi pada hari kiamat" (HR At Tabrani). Dengan begitu para pemimpin di sektor manapun bertanggung jawab menegakkan keadilan dan melayani dengan baik dan profesional. Jika tidak mampu maka akibatnya berat di belakang.

Demikian sekedar catatan pinggir tentang pemimpin yang adil. Secara konsep sudah banyak yang bisa dipedomani untuk menjadi pemimpin yang adil. Namun dalam implementasi tidaklah mudah. Karena banyak faktor yang bisa menggerus sikap adil. Bisa dari pemimpin sendiri yang tidak mampu mengendalikan diri, tidak disiplin, dan tak berintegritas. Juga bisa berasal dari keluarga dan handai taulan. Bisa juga dari pihak lain yang memaksa dan menjerat pemimpin.

Apapun alasannya, yang pokok adalah kuncinya di pemimpin sendiri. Bertanya pada hati nurani sendiri. Sudah adilkah saya. Sudah bebaskah saya dari sikap diskriminatif, 
menganakemaskan seseorang, kelompok atau institusi. Yang jelas adanya keberanian melayani orang atau pihak lain satu strip di atas kita, keluarga kita, kelompok kita, fraksi kita atau partai kita. Dengan begitu insya Allah pemimpin bisa menenuhi sikap adil, di samping melayani. Semoga. ${ }^{7}$

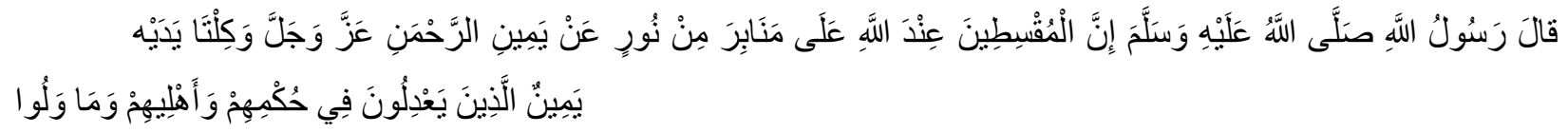

"Sesungguhnya orang-orang yang berbuat adil di mata Allah berada di atas mimbar yang terbuat dari cahaya, berada di sebelah kanan Ar-Rahman Azza wa Jalla. Yaitu mereka yang berbuat adil ketika menetapkan putusan hukum, dan adil terhadap pengikut dan rakyanya." (HR. Muslim) ${ }^{8}$

\section{KEWAJIBAN MENTAATI PEMIMPIN}

Ketaatan kepada pemimpin adalah suatu kewajiban sebagaimana disebutkan dalam AlQur'an dan Hadits sangat banyak sekali. Dalil di dalam Al-Qur'an di antaranya adalah firman Allah $^{9}$

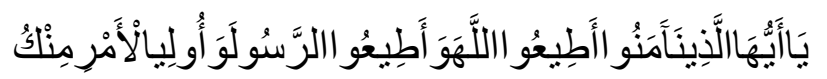

"Hai orang-orang yang beriman, taatilah Allah dan taatilah Rasul (Nya), dan ulil amri di antara kamu." (QS. An Nisa' [4]: 59)

Dalam ayat ini Allah menjadikan ketaatan kepada pemimpin pada urutan ketiga setelah ketaatan pada Allah dan Rasul-Nya. Namun, untuk pemimpin di sini tidaklah datang dengan lafazh perintah "taatilah" karena ketaatan kepada pemimpin merupakan ikutan (tâbi') dari ketaatan kepada Allah dan Rasul-Nya shallallahu 'alaihi wa sallam. Oleh karena itu, apabila seorang pemimpin memerintahkan untuk berbuat maksiat kepada Allah, maka tidak ada lagi kewajiban mendengar dan taat kepada mereka.

Rasulullah shallallahu 'alaihi wa sallam bersabda,

\footnotetext{
${ }^{7}$ Artikel prof.dr. rochmat wahab,m.pd.,ma

${ }^{8}$ Sahih Muslim, Hadits ke 3406, Jilid 9, hal 349.

${ }^{9}$ https://islam.nu.or.id/post/read/106733/sikap-terhadap-pemimpin-menurut-ajaran-islam
} 


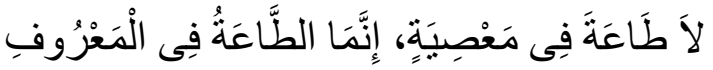

"Tidak ada kewajiban taat dalam rangka bermaksiat (kepada Allah). Ketaatan hanyalah dalam perkara yang ma'ruf (bukan maksiat)." 10

Rasulullah shallallahu 'alaihi wa sallam juga bersabda,

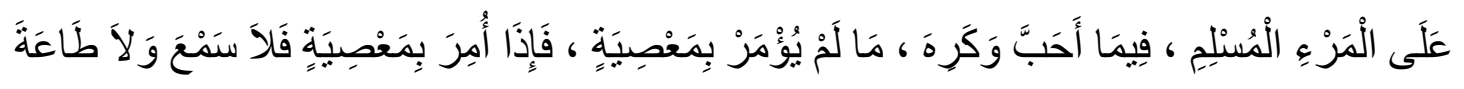

"Seorang muslim wajib mendengar dan taat dalam perkara yang dia sukai atau benci selama tidak diperintahkan untuk bermaksiat. Apabila diperintahkan untuk bermaksiat, maka tidak ada kewajiban mendengar dan taat." ${ }^{11}$

\section{AMAR MA'RUF NAHI MUNKAR KEPADA PEMIMPIN}

Amar ma'ruf nahi munkar, merupakan sebuah amalan yang sangat mulia. Dengannya terbangun kehidupan masyarakat Islami yang luar biasa, dinamis, harmonis, dan religius. Amalan ini harus digulirkan dengan baik, baik kepada golongan masyarakat yang paling rendah yaitu rakyat jelata, hingga golongan masyarakat yang paling tinggi yaitu para pemimpin ataupun penguasa.

Baik dan buruknya kehidupan bermasyarakat sebuah komunitas tergantung kepada siapa yang memimpin. Jika pemimpin ataupun penguasa komunitas tersebut memimpin dengan keshalihan, keilmuan, dan kecerdasan yang ia miliki dan dalam kepemimpinan tersebut bertujuan untuk mensejahterakan sebuah komunitas yang dipimpinnya, maka akan baiklah komunitas tersebut. Dan jika para penguasa tersebut memimpin serta memerintah dengan segala keburukan yang ia miliki dan didasari dengan hawa nafsu, maka akan buruk bahkan hancurnya komunitas tersebut.

\footnotetext{
${ }^{10}$ HR. Bukhari no. 7257

${ }^{11}$ HR. Bukhari no. 7144
} 
Fungsi amar ma'ruf nahi munkar kepada penguasa merupakan sesuatu yang sangat urgen dan sangat dibutuhkan, karena jika kita tengok realita akan rusaknya kehidupan bermasyarakat terkhusus di negeri ini yaitu Indonesia. Para penguasa dan pemimpinnya yang tidak menerapkan hukum Islam, pribadi yang tunduk pada hegemoni para konspirator, boneka asing, dan lain sebagainya. Sehingga, para penguasa dan pemimpin tersebut yang mungkin semula menginginkan kesejahteraan masyarakat dalam kepemimpinannya, berubah kepada hilangnya tujuan tersebut dan menuju pada kepemerintahan ataupun kepemimpinan yang hanya berdasarkan pada hukum manusia dan hawa nafsu. ${ }^{12}$

Al-Imam Sufyan ats-Tsauri berkata:

$$
\begin{aligned}
& \text { لا يأمر بالمعروف وينهى عن المنكر إلا من كان فيه ثلاث خصال: رفيق بما يأمر ، رفيق بما ينهى، عدل بما يأمر، }
\end{aligned}
$$

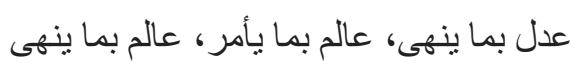

"Seseorang tidak boleh melakukan amar ma'ruf nahi munkar melainkan ada pada dirinya tiga perangai: lemah lembut ketika menyeru dan mencegah, adil ketika menyeru dan mencegah, mengilmui sesuatu yang diseru dan dicegahnya."13

\footnotetext{
${ }^{12}$ https://www.annursolo.com/amar-maruf-kepada-penguasa/

${ }^{13}$ Ibnu Rajab al-Hanbali, Jami'ul Ulum wal Hikam
} 


\section{PENUTUP}

\section{KESIMPULAN}

Kepemimpinan adalah adalah proses mempengaruhi aktivitas-aktivitas sebuah kelompok yang diorganisasi ke arah pencapaian tujuan. Dalam pengertian lain kepemimpinan adalah kemampuan dan keterampilan seseorang yang menduduki jabatan sebagai pimpinan satuan kerja untuk mempengaruhi orang lain, terutama bawahannya, untuk berfikir dan bertindak sedemikian rupa sehingga melalui perilaku yang positif ia memberikan sumbangan nyata dalam pencapaian tujuan organisasi. Sedangkan penertian manajemen adalah suatu proses perencanaan, pengorganisasian, kepemimpinan dan pengendalian upaya dari anggota organsasi serta penggunaan semua sumber daya yang ada pada organisasi untuk mencapai tujaun organisasi yang telah ditetapkan sebelumnya.

Keberadaan dan kemajuan suatu organisasi atau institusi sangatlah tergantung pada pemimpinnya. Baik itu berkenaan dengan sifat maupun sikap pemimpin. Adil merupakan salah satu sifat dan sikap pemimpin yang sangat penting, selain jujur, bertanggung jawab, kreatif, visioner, perduli, komunikatif, dan sebagainya. Pemimpin yang adil tidak hanya berurusan secara horizontal, melainkan juga berurusan secara vertikal. Justru pemimpin yang adil ada di mata Allah swt. Dengan begitu betapa berartinya pemimpin yang adil.

Ketaatan kepada pemimpin adalah suatu kewajiban sebagaimana disebutkan dalam AlQur'an dan Hadits sangat banyak sekali. 


\section{DAFTAR PUSTAKA}

abu 'abd allah Muhammad bin ismail al-bukhari, shahih bukhari, kitab ahkam,bab qoulillahi ta'ala athi'ullah,(berikut lenanon: dar al-kutub al-ilmiyah, 1992), juz VII. H 444

Artikel prof.dr. rochmat wahab,m.pd.,ma

https://islam.nu.or.id/post/read/106733/sikap-terhadap-pemimpin-menurut-ajaran-islam

https://www.annursolo.com/amar-maruf-kepada-penguasa/

HR. Bukhari no. 7257

HR. Bukhari no. 7144

Ibnu Rajab al-Hanbali, Jami'ul Ulum wal Hikam

James A.F. stoner

Kusnadi "Pengantar Manajemen (Konsepsual \& Perilaku)" 2005 hal. 353

Rebecca "Analisis Perencanaan Implementasi dan Kontrol”(dalam http://vianneyjkt.sch.id/a185m23s/ kepemimpinan-yang-efektif.html)

Sahih Muslim, Hadits ke 3406, Jilid 9, hal 349.

Winardi “Kepemimipinan dalam Manajemen” 2000:47 
